\title{
THE EFFECT OF L-SHAPED RC SHEAR WALL ON STUDENT DORMITORY BUILDING OF ANDALAS UNIVERSITY, PADANG- INDONESIA
}

\author{
*Fauzan ${ }^{1}$, Febrin Anas Ismail², Muhammad Warsa Rizki ${ }^{3}$, Irsyadul Fikri ${ }^{4}$, and Zev Al Jauhari ${ }^{5}$ \\ ${ }_{1,2,3,4}$ Civil Engineering Department, Andalas University, Indonesia; ${ }^{5}$ Bengkalis State Polytechnic, Indonesia \\ *Corresponding Author, Received: 03 March 2020, Revised: 03 April 2020, Accepted: 15 April 2020
}

\begin{abstract}
Student Dormitory of Andalas University is one of the buildings for new students who come from outside of Padang, Indonesia. In 2015, Andalas University received aid from the Public Works Ministry of Indonesia to build the dorm. It was planned by a designed consultant using reinforced concrete (RC) structure with a straight shape (I-shaped) RC shear wall. The review results of the design from the Technical Engineer of Andalas University indicated that the designed building does not have enough carrying capacity to resist the accumulation of all combined internal and external loads acting on the building structure. Therefore, the strengthening of the building structure should be done. In the present study, the strengthening method is proposed by modifying the I-shaped RC shear wall (I-shear wall) to be L-shaped RC shear wall (Lshear wall), which is installed at the building corners. The L-shear wall was installed on the building in two ways, that is only on the $1^{\text {st }}$ floor $\left(2^{\text {nd }}-5^{\text {th }}\right.$ stories using I-shear wall) and on all building stories. The effect of the L-shear wall in the building performance has been investigated based on parameters such as internal forces of structural elements, story displacement, and story drift. The presence of L-shear wall only on the $1^{\text {st }}$ floor reduced the shear force and bending moment of columns and beams on the $1^{\text {st }}$ floor and no much effect on the other floors, while the addition of the L-shear wall on all stories decreased the internal forces on columns and beams in all stories. The reduction of the inter-story drift of the building was more decreased by the installment of the L-shear wall on all stories.
\end{abstract}

Keywords: Shear wall, Dormitory building, Earthquake load, RC structure, Structural response

\section{INTRODUCTION}

The structure of multi-story buildings is vulnerable to lateral force, especially for the force caused by the earthquake. Earthquakes are events of earth movement caused by the release of energy in the earth suddenly. The earthquakes are caused by geologic activity that occurs in the earth, such as the shift between continental plates leading earthquakes [1]. Earthquake risk, especially in Padang, has resulted in damage to the building, which needs a strong structure to resist the force caused by the earthquake. One way to strengthen the building is by using the structural reinforcement shear wall $[2,3]$. The reinforced concrete shear wall is one of the most effective building elements in providing earthquake resistance to the building [4]. The RC shear wall generally was installed in the building as a vertical structural element for resisting the lateral loads that serve as a stiffener which proceeds to the foundation [5]. With the rigid shear walls in the building, most of the earthquake loads in multistory buildings will be absorbed by the wall $[6,7]$. It is well-known that the shear wall carries most of the earthquake loadings and helps to decrease the damage level of columns [8]. One advantage of using a shear wall is easy to construct by installing the steel reinforcement on walls and then casting the concrete. The performance of the building is mainly affected by the location of the shear wall and the reinforced shear wall high in-plane stiffness. Therefore, the position of the shear wall in an ideal location will improve the performance of buildings [9].

A reinforced concrete (RC) structure building of the Student Dormitory of Andalas University was planned by a designed consultant using the RC frame structure with a straight shape (I-shaped) $\mathrm{RC}$ shear wall in 2015. Based on a review of the design from the Technical Engineer of Andalas University, it is found that the designed building does not have enough carrying capacity to resist the accumulation of all combined internal and external loads acting on the building structure. Therefore, there is a need to provide strengthening for the building structure. In this study, the strengthening method has been proposed by modifying the I-shaped RC shear wall (I-shear wall) to be L-shaped RC shear wall (L-shear wall), which is installed at the building corners [10]. Shear walls are installed at the building corners in L-shaped to increase the seismic behavior of the building. The effect of the L-shear wall in the 
building behavior has been investigated based on parameters such as internal forces (axial, shear, and bending moment) of structural elements, story displacement, and story drift.

\section{3D MODEL AND ANALYSIS OF THE STRUCTURES}

Modeling and analyzing structures of the dormitory building are carried out by using 3D structural modeling with ETABS v9.7.1 software [11]. Figs. 1 and 2 show the view and plan of the building.

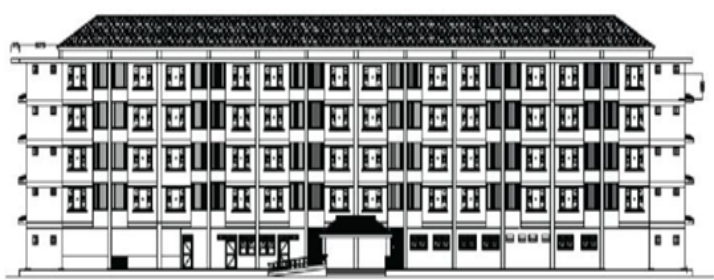

(a)

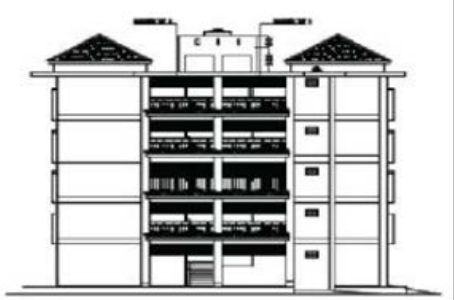

(b)

Fig.1 (a) The front and (b) side views of the Dormitory Building of Andalas University [12]

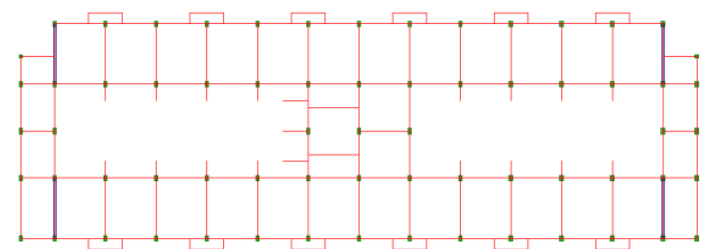

(a)

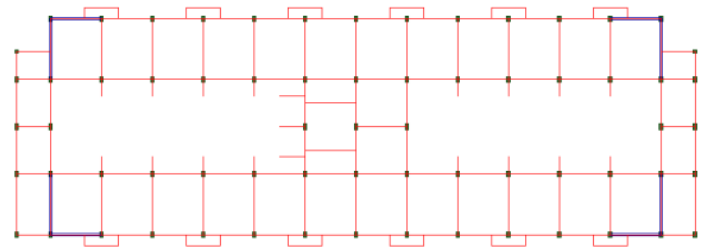

(b)

Fig.2 The plan of the dormitory building with (a) I-shear wall and (b) L-shear wall systems

\subsection{Modeling}

To perform the analysis of the structure, the following technical data of the building from design consultant was used [12]: (a) Location: Andalas University, Limau Manis, Padang; (b) Type of structures: reinforced concrete; (c)
Concrete comp. strength, $\mathrm{f}^{\prime}{ }_{\mathrm{c}}=29.05 \mathrm{MPa}$; (d) Yield stress of steel, $\mathrm{f}_{\mathrm{y}}=390 \mathrm{MPa}$; and (e) Number of floors: 5 .

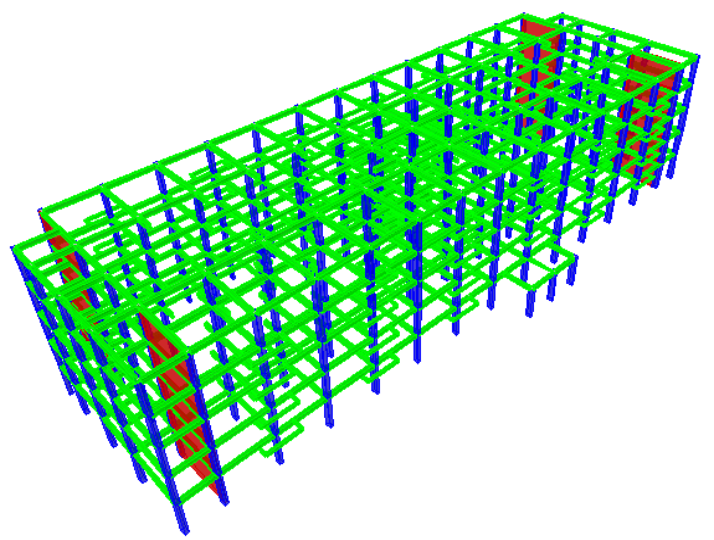

(a)

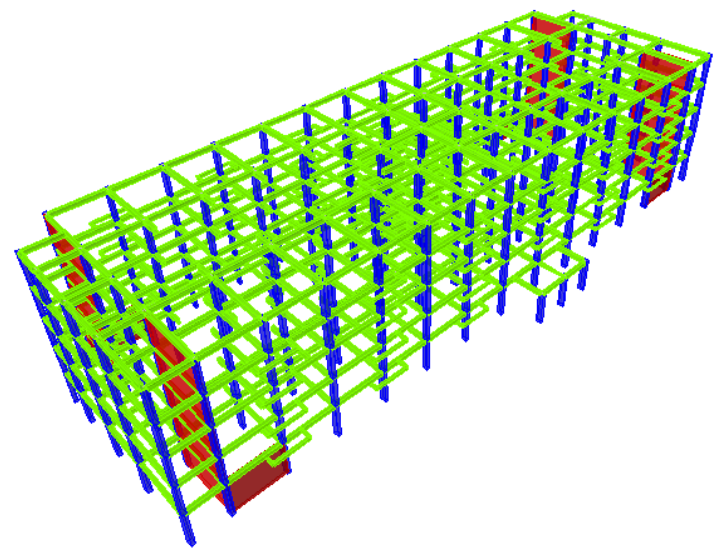

(b)

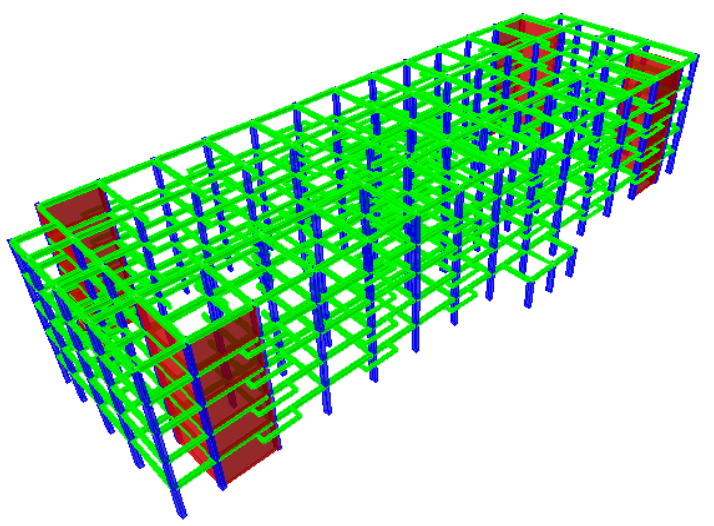

(c)

Fig.3 The structure modeling of the student dormitory building with (a) I-shear wall; (b) Lshear wall only on $1^{\text {st }}$ floor; (c) L-shear wall on all stories

Columns and beams in the building were modeled as frame elements, while slabs, stairs, and shear walls were modeled as a wall element, as shown in Fig. 3. In this study, L-shear walls were installed on the corners of the building on the $1^{\text {st }}$ floor only (Fig. 3 (b)) and on all stories (Fig. 3 (c)). 


\subsection{The Design of Loads}

The calculation of the dead load is taken by its weight building materials and components of the building. Live load is modeled based on SNI 1727:2013, which are taken based on criteria for the use of floor in the dormitory building, for residential area: $250 \mathrm{~kg} / \mathrm{m}^{2}$ and for torn water area: $2000 \mathrm{~kg} / \mathrm{m}^{2}$ [13].

\subsection{Spectrum Response Analysis}

Response Spectrum Analysis (RSA) is a linear dynamic statistical analysis method which measures the contribution from each eigen mode to indicate the likely maximum seismic response of an elastic structure. RSA is favored by earthquake engineering community because it offers a simplified method for finding the design forces for structural members for earthquake and for evaluating the seismic reliability of structures.

In this study, the spectrum response design for earthquake load based on SNI 1726:2012 [14] was used for RSA. According to the soil test result, the soil on the building are was classified as soft soil. Fig. 4 shows the spectrum response design on the soft soil type of Padang.

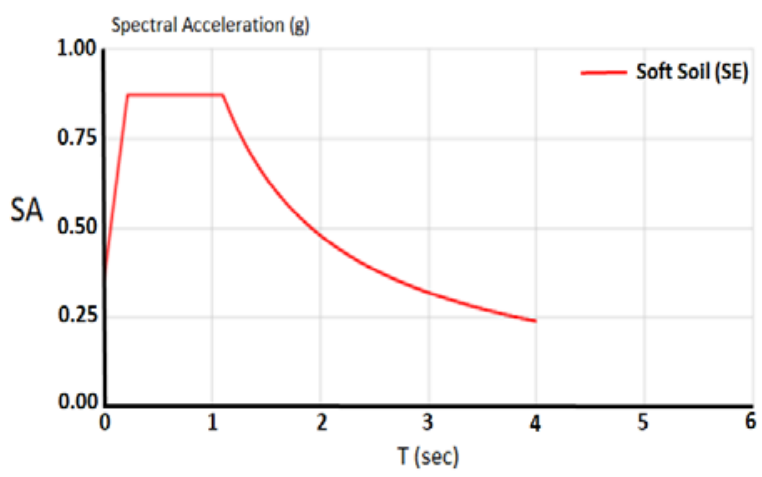

Fig.4 Spectrum response design for earthquake load in Padang based on SNI 1726:2012

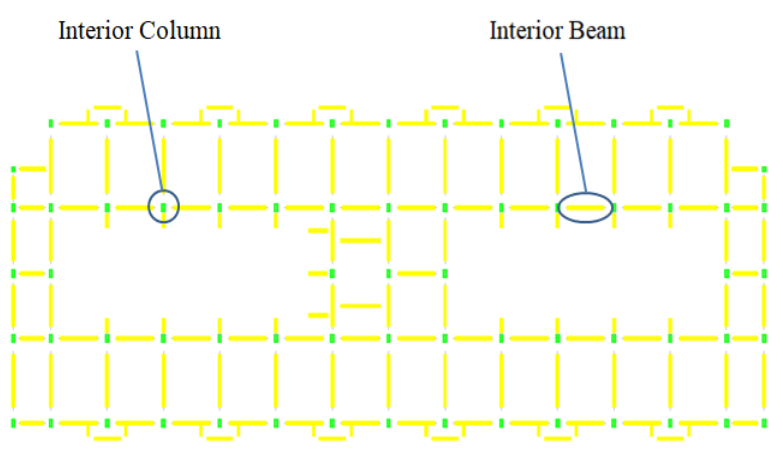

Fig.5 The location point of structural element to compare the analysis results
In order to compare the structural responses of column and beam elements, an interior column and an interior beam in each floor was observed. The location points of the interior column and the interior beam used to review the structural responses are shown in Fig. 5.

\section{RESULT OF STRUCTURAL ANALYSIS}

In this study, the results of structural analysis such as internal forces and displacement of the buildings with L-shear walls were compared with the I-shaped one.

\subsection{Internal Forces in Columns}

Fig. 6 shows the comparison of the internal forces in the interior column between the building using the I-shear wall and the building using the Lshear wall on the $1^{\text {st }}$ floor. From Fig. 6 , it is viewed the axial force in the interior column on the building with the I-shear wall was similar to the Lshear wall installed on the $1^{\text {st }}$ floor, whereas the shear force and bending moments of the column decreased significantly in the $1^{\text {st }}$ floor of the building. The shear and bending moment in the $1^{\text {st }}$ floor have reduced by $90 \%$ and $84 \%$, respectively.

Similar results were also found out in the building with the L-shear wall installed on all stories. As seen in Fig. 7, the axial force of the building is almost similar to one with the I-shear wall. However, the significant decrease of shear force and bending moment of this building were found out on all stories. This indicated that the presence of the L-shear wall on all stories increases the capacity of the structure, in which the shear wall reduces the shear force and bending moment of the column on all stories significantly.

\subsection{Internal Forces in Beams}

Fig. 8 shows the comparison of internal force in the interior beam between the building using the I-shear wall and the building using the L-shear all on the $1^{\text {st }}$ floor. From this figure, it can be seen that the installment of the L-shear wall only on the $1^{\text {st }}$ floor of the building affected the beam internal forces, especially the shear force and bending moment. The shear and bending moment on the $1^{\text {st }}$ floor have reduced by $23 \%$ and $35 \%$, respectively.

Similarly, the presence of the L-shear wall on all stories of the building reduced the internal forces of the beam on all stories, as shown in Fig. 9. It is viewed the shear force and bending moment were decreased by about $25-40 \%$ and $39-60 \%$, respectively. 


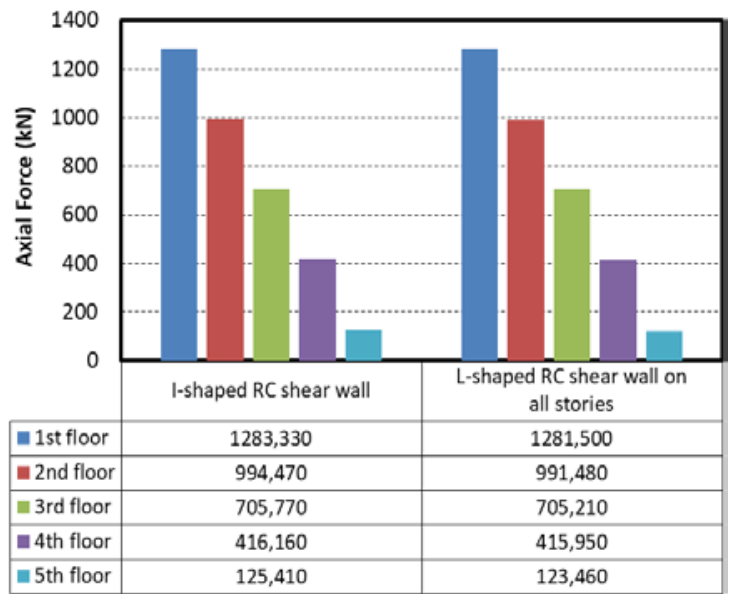

(a)

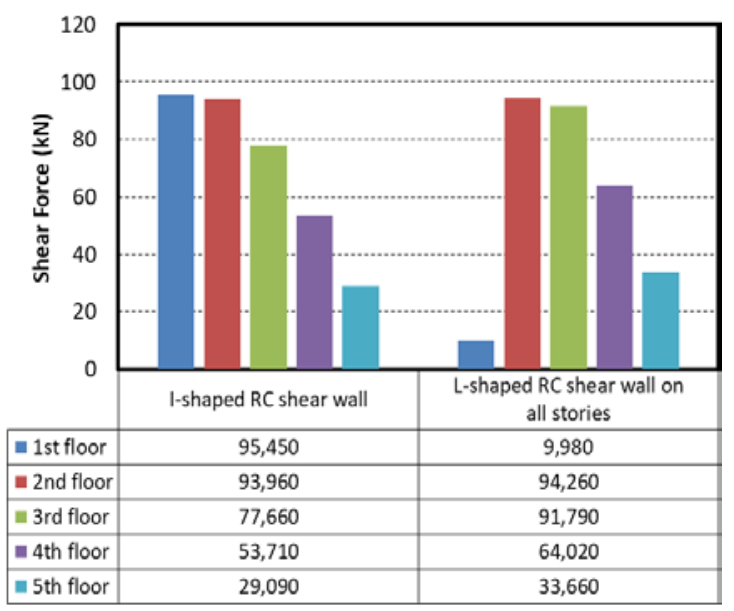

(b)

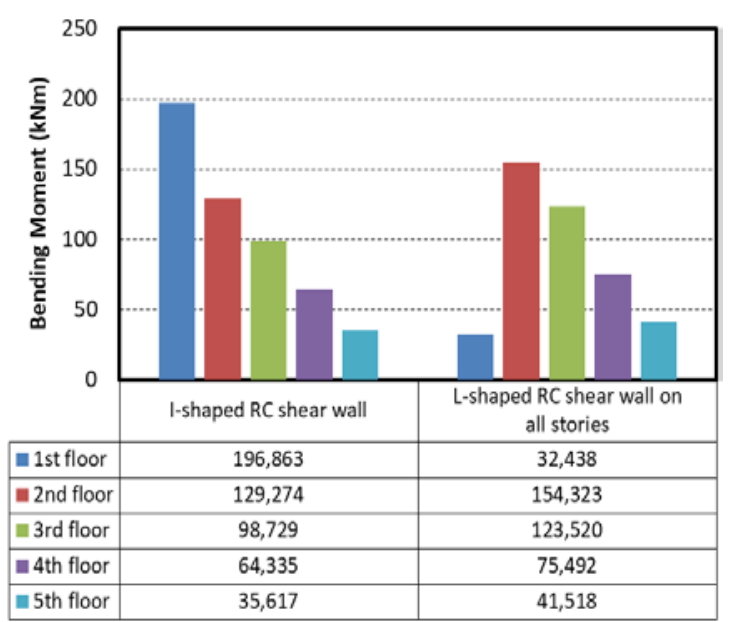

(c)

Fig.6 The comparisons of (a) axial force; (b) shear force; (c) bending moment in the interior column between the building using the I-shear wall and the building using the L-shear wall on all stories.

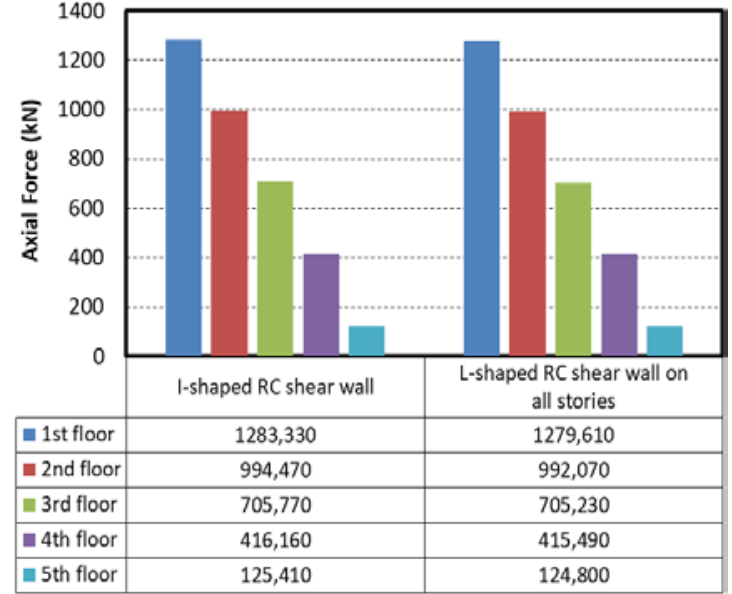

(a)

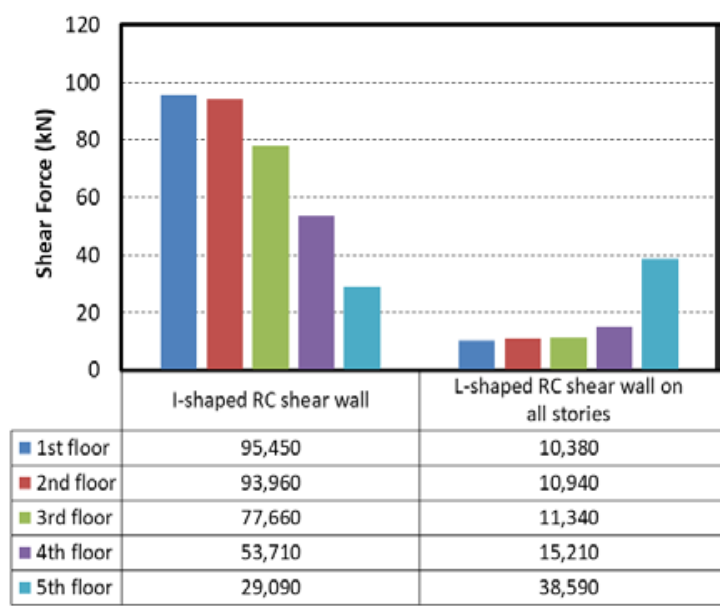

(b)

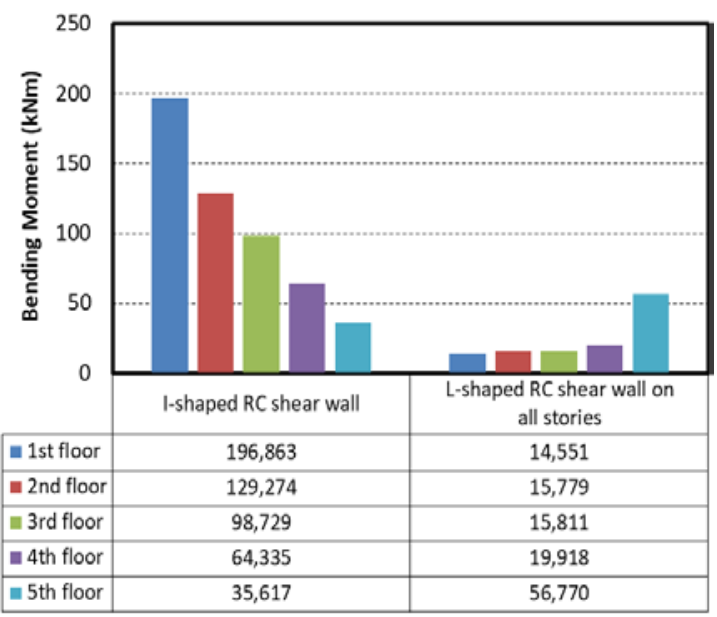

(c)

Fig.7 The comparisons of (a) axial force; (b) shear force; (c) bending moment in the interior column between the building using the I-shear wall and the building using the L-shear wall on all stories. 


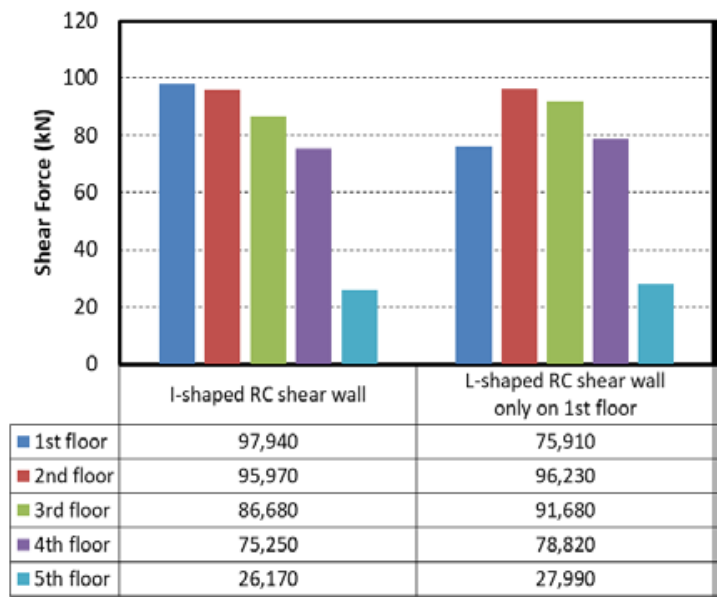

(a)

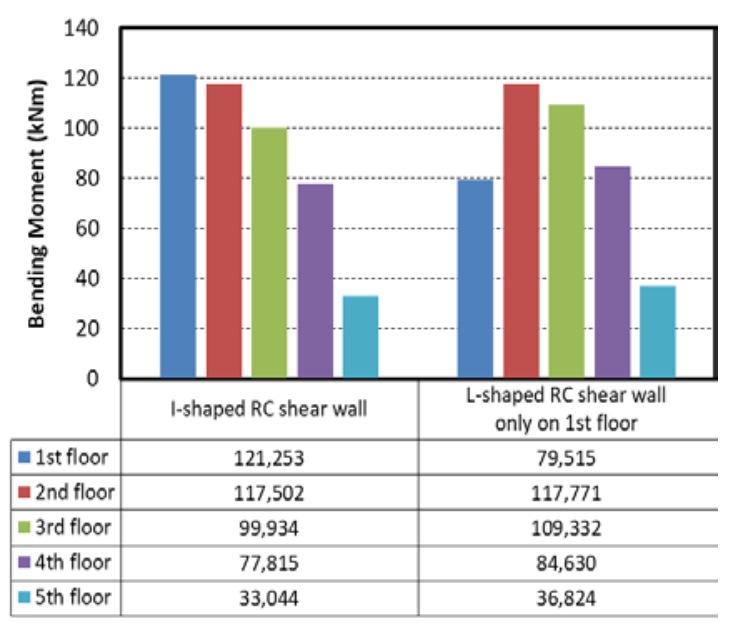

(b)

Fig.8 The comparisons of (a) shear force; (b) bending moment in the interior beam between the building using the I-shear wall and L-shear wall installed only on the $1^{\text {st }}$ floor.

\subsection{Displacements}

Fig. 10 shows the comparison of displacement between the building using the I-shear wall and the building using the L-shear wall on the $1^{\text {st }}$ floor. Displacement of the building structure is taken from the largest value of displacement in each floor. As seen in the figure, the presence of the L-shear wall on the $1^{\text {st }}$ floor of the building reduces displacement of the building in $\mathrm{X}$ direction about $20 \%$ on the top floor, while a slight decrease was found in Y-direction displacement.

A similar trend was also found in the building with the L-shear wall installed on all stories. As seen in Fig. 11, the presence of the L-shear wall on all stories reduced significantly the displacement in the $\mathrm{X}$-direction and slightly reduced in the $\mathrm{Y}$ direction. The maximum reduction of displacement in the X-direction is about $59 \%$ on the top floor of the building.

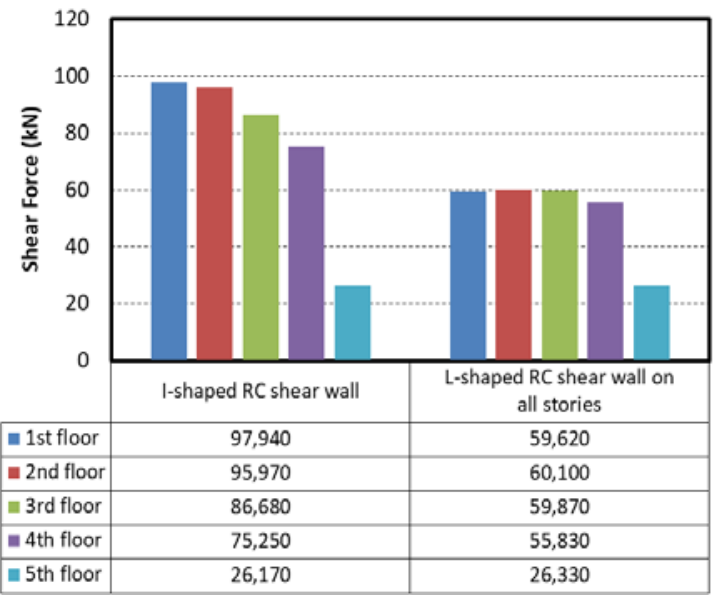

(a)

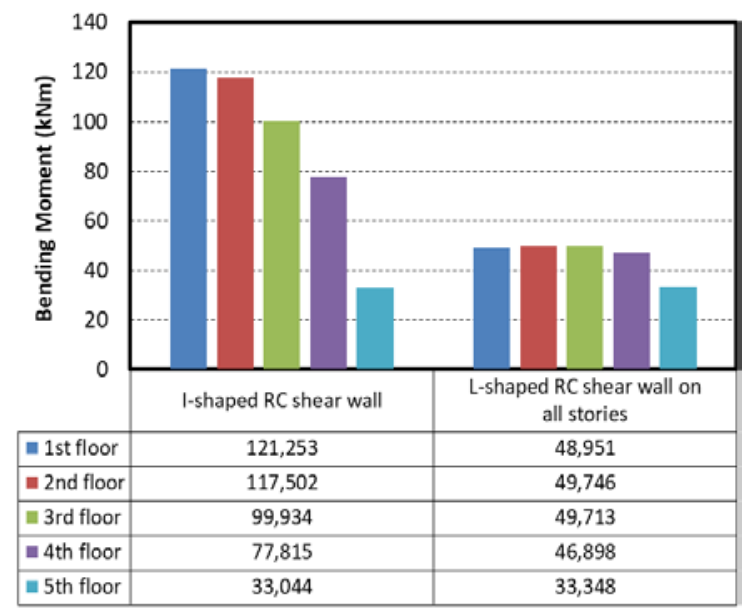

(b)

Fig.9 The comparisons of (a) shear force; (b) bending moment in the interior beam between the building using the I-shear wall and L-shear wall on all stories.

\subsection{Inter-story Drift}

The values of the inter-story drift of the building with the L-shear wall installed only on the $1^{\text {st }}$ floor and L-shear wall on all stories in X and Ydirections can be seen in Tables 1, 2, 3, and 4, respectively.

As seen from the tables, the inter-story drift of the building due to the presence of the L-shear wall installed only on the $1^{\text {st }}$ floor and on all stories meets the requirement based on standard code SNI $1726: 2012$. For all story variants considered, the inter-story drift is greatest for the building using Lshear wall installed only on the $1^{\text {st }}$ floor. It occurs in the third story, with the value $51.98 \mathrm{~mm}$ at the $\mathrm{X}$-direction. Taken away from the tables, these show that the presence of the L-shear wall on all stories of the building reduced significantly the inter-story drift, especially in the X-direction. 


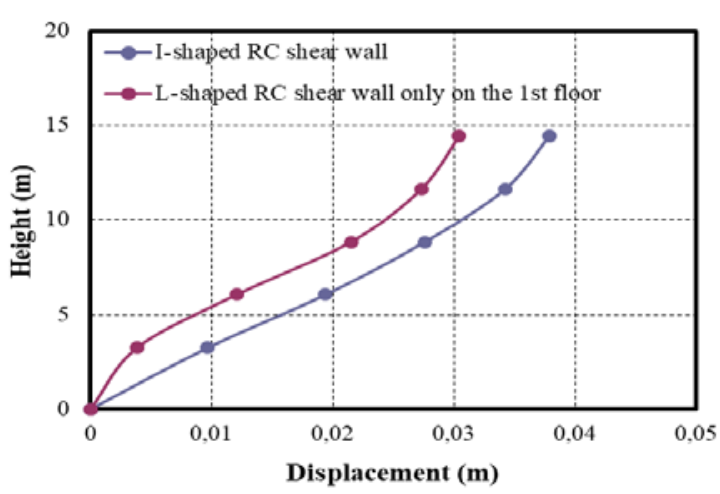

(a)

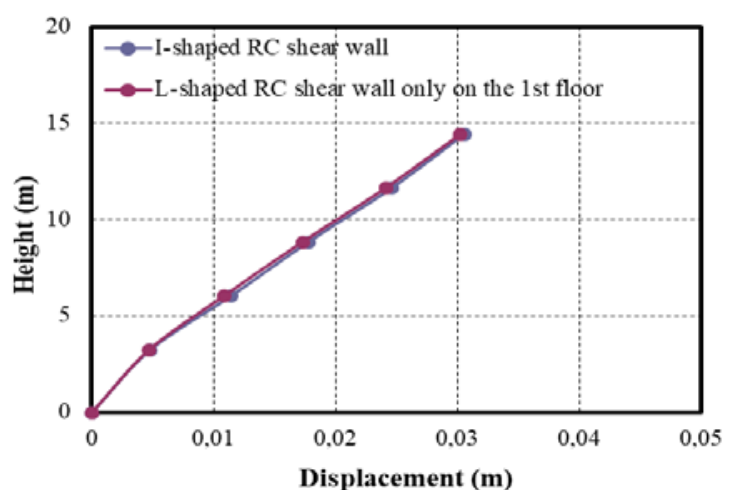

(b)

Fig.10 The comparison of displacement in (a) Xdirection; (b) Y-direction between the building using the I-shear wall and the building using the Lshear wall only on the $1^{\text {st }}$ floor

Table 1 Inter-story drift in the X-direction of the building using L-shear wall installed only on the $1^{\text {st }}$ floor

\begin{tabular}{ccccccc}
\hline Story & $\begin{array}{c}\mathrm{H} \\
(\mathrm{mm})\end{array}$ & $\begin{array}{c}\mathrm{UX} \\
(\mathrm{mm})\end{array}$ & $\begin{array}{c}\text { Drift X } \\
(\mathrm{mm})\end{array}$ & $\begin{array}{c}\Delta \mathrm{s} X \\
(\mathrm{~mm})\end{array}$ & $\begin{array}{c}\Delta \mathrm{a} \\
(\mathrm{mm})\end{array}$ & $\begin{array}{c}\Delta \mathrm{s} \mathrm{X} \\
\leq \Delta \mathrm{a}\end{array}$ \\
\hline Base & 0 & 0 & 0 & 0 & 0 & OK \\
1 & 3250 & 3.84 & 3.84 & 21.12 & 62.5 & OK \\
2 & 2800 & 12.06 & 8.22 & 45.21 & 53.85 & OK \\
3 & 2800 & 21.51 & 9.45 & 51.98 & 53.85 & OK \\
4 & 2800 & 27.32 & 5.81 & 31.96 & 53.85 & OK \\
5 & 2800 & 30.41 & 3.09 & 16.99 & 53.85 & OK \\
\hline
\end{tabular}

Table 2 Inter-story drift in the Y-direction of the building using L-shear wall installed only on the $1^{\text {st }}$ floor

\begin{tabular}{ccccccc}
\hline Story & $\begin{array}{c}\mathrm{H} \\
(\mathrm{mm})\end{array}$ & $\begin{array}{c}\mathrm{UY} \\
(\mathrm{mm})\end{array}$ & $\begin{array}{c}\text { Drift Y } \\
(\mathrm{mm})\end{array}$ & $\begin{array}{c}\Delta \mathrm{s} \mathrm{Y} \\
(\mathrm{mm})\end{array}$ & $\begin{array}{c}\Delta \mathrm{a} \\
(\mathrm{mm})\end{array}$ & $\begin{array}{c}\Delta \mathrm{s} \mathrm{Y} \\
\leq \Delta \mathrm{a}\end{array}$ \\
\hline Base & 0 & 0 & 0 & 0 & 0 & $\mathrm{OK}$ \\
1 & 3250 & 4.68 & 4.68 & 25.74 & 62.5 & $\mathrm{OK}$ \\
2 & 2800 & 10.83 & 6.15 & 33.83 & 53.85 & $\mathrm{OK}$ \\
3 & 2800 & 17.27 & 6.44 & 35.42 & 53.85 & $\mathrm{OK}$ \\
4 & 2800 & 24.10 & 6.83 & 37.57 & 53.85 & $\mathrm{OK}$ \\
5 & 2800 & 30.24 & 6.14 & 33.77 & 53.85 & $\mathrm{OK}$ \\
\hline
\end{tabular}

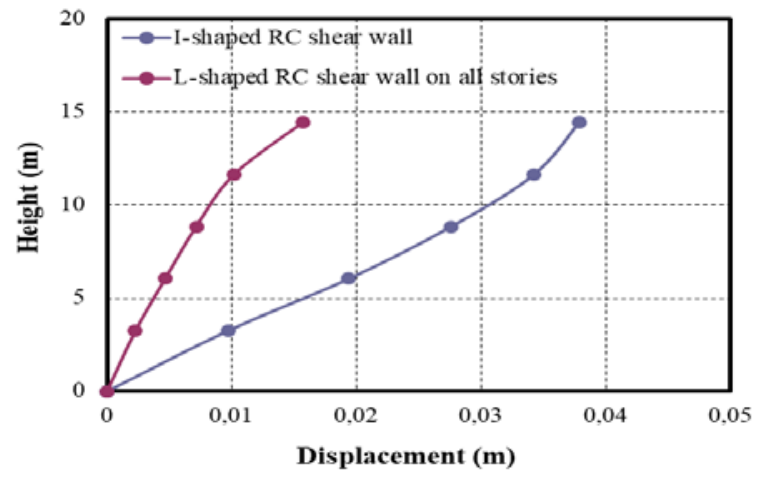

(a)

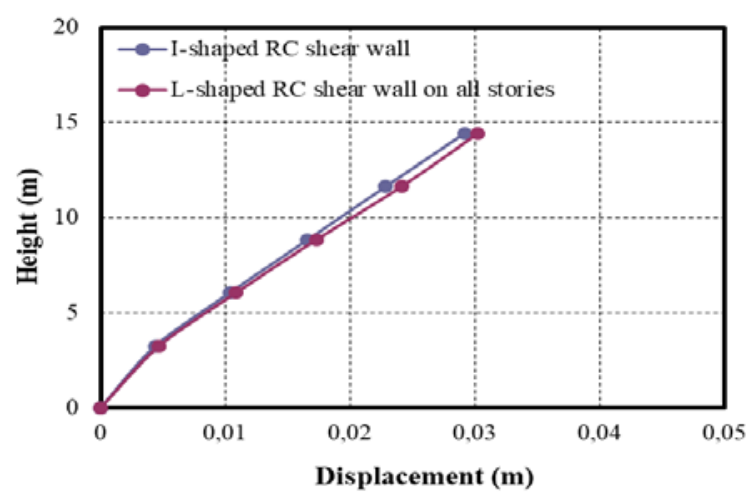

(b)

Fig.11 The comparison of displacement in (a) Xdirection; (b) Y-direction between the building using the I-shear wall and the building using the Lshear wall on all stories.

Table 3 Inter-story drift in the X-direction of the building using L-shear wall on all stories

\begin{tabular}{ccccccc}
\hline Story & $\begin{array}{c}\mathrm{H} \\
(\mathrm{mm})\end{array}$ & $\begin{array}{c}\mathrm{UX} \\
(\mathrm{mm})\end{array}$ & $\begin{array}{c}\text { Drift X } \\
(\mathrm{mm})\end{array}$ & $\begin{array}{c}\Delta \mathrm{s} \mathrm{X} \\
(\mathrm{mm})\end{array}$ & $\begin{array}{c}\Delta \mathrm{a} \\
(\mathrm{mm})\end{array}$ & $\begin{array}{c}\Delta \mathrm{s} \mathrm{X} \\
\leq \Delta \mathrm{a}\end{array}$ \\
\hline Base & 0 & 0 & 0 & 0 & 0 & OK \\
1 & 3250 & 2.28 & 2.28 & 12.54 & 62.5 & OK \\
2 & 2800 & 4.66 & 2.38 & 13.09 & 53.85 & $\mathrm{OK}$ \\
3 & 2800 & 7.15 & 2.49 & 13.69 & 53.85 & $\mathrm{OK}$ \\
4 & 2800 & 10.19 & 3.04 & 16.72 & 53.85 & $\mathrm{OK}$ \\
5 & 2800 & 15.72 & 5.53 & 30.41 & 53.85 & $\mathrm{OK}$ \\
\hline
\end{tabular}

Table 4 Inter-story drift in the Y-direction of the building using L-shear wall on all stories

\begin{tabular}{ccccccc}
\hline Story & $\begin{array}{c}\mathrm{H} \\
(\mathrm{mm})\end{array}$ & $\begin{array}{c}\mathrm{UY} \\
(\mathrm{mm})\end{array}$ & $\begin{array}{c}\text { Drift Y } \\
(\mathrm{mm})\end{array}$ & $\begin{array}{c}\Delta \mathrm{s} \mathrm{Y} \\
(\mathrm{mm})\end{array}$ & $\begin{array}{c}\Delta \mathrm{a} \\
(\mathrm{mm})\end{array}$ & $\begin{array}{c}\Delta \mathrm{s} \mathrm{Y} \\
\leq \Delta \mathrm{a}\end{array}$ \\
\hline Base & 0 & 0 & 0 & 0 & 0 & $\mathrm{OK}$ \\
1 & 3250 & 4.39 & 4.39 & 24.14 & 62.5 & $\mathrm{OK}$ \\
2 & 2800 & 10.34 & 5.95 & 32.72 & 53.85 & $\mathrm{OK}$ \\
3 & 2800 & 16.59 & 6.25 & 34.37 & 53.85 & $\mathrm{OK}$ \\
4 & 2800 & 22.83 & 6.24 & 34.32 & 53.85 & $\mathrm{OK}$ \\
5 & 2800 & 29.17 & 6.34 & 34.87 & 53.85 & $\mathrm{OK}$ \\
\hline $\mathrm{a}=0.015 \times \mathrm{H} / \rho ; \Delta \mathrm{s}=\delta \times \mathrm{C}_{\mathrm{d}} / \mathrm{I}_{\mathrm{e}}$
\end{tabular}




\section{CONCLUSION}

- The presence of L-shear wall that was installed only on the $1^{\text {st }}$ floor of the dormitory building reduced the column's shear and bending moment on the $1^{\text {st }}$ floor about $90 \%$ and $84 \%$, respectively and no much affect the other floors, while the addition of the L-shear wall on all stories decreased the column's shear force and bending moment in all floors.

- The addition of the L-shear wall only on the $1^{\text {st }}$ floor of the building reduced the beam's shear force and bending moment about $23 \%$ and $35 \%$, respectively, while the presence of the L-shear wall on all stories reduced the internal forces of the beam on all floors.

- The presence of the L-shear wall reduced the building displacement, especially in Xdirection. The reduction of the displacement in $\mathrm{X}$-direction reached $59 \%$ for building with the L-shear wall installed on all stories.

- Inter-story drift of the building with the Lshear wall meets the requirement based on standard code SNI 1726:2012. The reduction of the inter-story drift of the building was more decreased by instalment of the L-shear wall on all stories, especially in X-direction.

\section{ACKNOWLEDGEMENTS}

The authors would like to thank the Engineering Faculty of Andalas University for financial support in publishing this article.

\section{REFERENCES}

[1] Purwono R., The Design of EarthquakeResistant Structures, Jakarta, ITS Press, 2010.

[2] Fintel M., Shear wall an Answer for Seismic Resistence, ACI Structural Journal, Vol. 13 (7), 1991, pp. 48-53.

[3] Rina Y., Fauzan, Abdul H., Helza R., Structural Evaluation of Nurul Haq Shelter Building Constructed on Liquefaction Prone Area in Padang City-Indonesia, Int. Journal of GEOMATE, Vol. 17, Issue 59, July 2019, pp.106-114.
[4] Himalee R., Satone S. R., Design and Analysis of Multi-storied Building with Effect of Shear Wall, Int. Journal of Eng. Research and App., Vol. 3, Issue 3, 2013, pp. 223-232.

[5] Ismail M., Analysis of Structural Performance on Seven Floors Building with Dimension and Location Variations of Shear Wall, J. of Civil and Enviromental Eng., Vol. 2, No. 1, 2014.

[6] Madhu S. R. K., Optimum location of a shear wall in a R.C building, International Journal of Scientific \& Engineering Research, Vol. 9, Issue 7, 2018, pp. 152- 159.

[7] Richa G., Alfia B., Performance Evaluation of Various Shapes of Shear Wall using Response Spectrum Analysis, International Journal of Recent Technology and Engineering (IJRTE), Vol. 8, Issue 1, May 2019.

[8] Seyit A. K., Tulay A. O., Muzaffer B., Basak Z., Ali K., Modeling The RC Frame Buildings with Shear Walls as Fictive Frame Element and Performance Evaluation of this Type of Buildings, Proceedings of The IRES $27^{\text {th }}$ Int. Conference, Thailand, 31 ${ }^{\text {st }}$ January 2016.

[9] Ryota I., Tetsuya O., A Study For Seismic Improvement of Concrete Frame with Perforated Walls, Int. Journal of GEOMATE, Vol. 10, No. 2, 2016, pp. 1784-1789.

[10] Israa H. N., Shereen Q. A., Zahraa M. K., The Effect of Shear Wall Locations in RC MultiStorey Building with Floating Column Subjected to Seismic Load, Int. Journal of Civil Eng. and Tech., Vol. 9, Issue 7, July 2018, pp. 642-651.

[11]CSI ETABS, ETABS Version 9.7.1, USA, 2013.

[12] Andalas University, Construction Report of Andalas University Dormitory Building, Padang, 2014.

[13]BSN of Indonesia, Minimum Load for The Design of Buildings and Other Structures, SNI 1727:2013, Jakarta, Indonesia, 2013.

[14]BSN of Indonesia, Design Method of Earthquake Resistance for Buildings and other Structures, SNI 1726:2012, Jakarta, Indonesia, 2012.

Copyright (C) Int. J. of GEOMATE. All rights reserved, including the making of copies unless permission is obtained from the copyright proprietors. 